Philosophy and Progress: Vols. LI-LII, January-June, July-December, 2012 ISSN 1607-2278 (Print), DOI : http://dx.doi.org/10.3329/pp.v51i1-2.17676

\section{PHILOSOPHY OF EDUCATION AN ISLAMIC PERSPECTIVE}

\section{Qazi Nusrat Sultana*}

"Read, in the name of thy Lord, and Cherisher, .... And thy Lord is Most Bountiful. He who taught the use of pen, taught man that which he knew not."

This was the first instruction that came to Prophet Muhammad from Allah. Beside this verse, in a number of other verses $^{2}$ Allah has asked human beings to study and acquire knowledge and make a good use of pen, because without these, man can never understand Allah and His creation properly. Following the instructions of Al-Qur'an, Prophet Muhammad (SM) also directed to acquire knowledge with utmost sincerity. And from these one can easily understand the place and importance of education in Islam. But unfortunately, the Muslims, except for a few and the eminent personalities of early periods after Prophet Muhammad (SM), all over the world as compared to other religionists, did seldom care for

\footnotetext{
* Professor of Philosophy and Retired Principal, Zaheda Safir Govt. Girl's College, Jamalpur. E-mail : nusrat2758@yahoo.com
}

education and even those who have obtained degrees and claim to have acquired knowledge have not, in most cases, understood the spirit either of Islam or of education. The present paper is a humble endeavour to explain education from Islamic perspective based mainly on Al-Qur'an and Sunnah as has been understood by the writer and put forward some personal views on the topic.

Before we start exploring what is education from Islamic point of view or what is the nature of Islamic philosophy of education we may try to say few words about the meaning of the expression 'Philosophy of Education' as understood by Western philosophers. Educational philosophers from the time of Plato wanted to have clear views about the purpose of education and the values which should govern it. Sir Richard Livingstone, in his book Education for a World Adrift (1943), talked about "standards; a philosophy of life; a principle by which to judge and rule it; a formula or formulas to integrate our civilization, our new order; some knowledge of the 'science of good and evil'" 3 Through these words, it seems, he means to say that before we take up the responsibility of educating the future generation we need a philosophy of education which in turn is the philosophy of life. Aristotle, in his 'The Politics', maintains :

What education is and how young persons should be educated are questions which demand consideration. ... No one knows on what principle should we proceed, whether the young should be exercised in that which is useful in life or goodness or should the higher knowledge be the aim of our training. All three points of view have been maintained. If there is no agreement about the aims, neither is there about the means. Different persons starting with different ideas about the 
nature of goodness, naturally disagree about the practice of it. ${ }^{4}$

The situation is somewhat same even today as it was at the time of Aristotle about two thousand and five hundred years ago. It is quite natural. We find as many views about the aims and nature of education as there are people who discuss them, who care about them. People could not declare an educational aim as final or applicable for all the ages coming ahead because the situation and the demands are changing from time to time, from place to place, from person to person. But this phenomenon is not a condition of despair. Philosophers with the treasure of wisdom have always come up to handle the situation. Russell puts it in a way of discussion that philosophy is the attempt to answer ultimate questions critically, after investigating all that makes such questions puzzling and after analyzing the vagueness and confusion that underlie our ordinary ideas. ${ }^{5}$ As in any other field, philosophy tries to find out answers to the critical questions arising in the field of education also. In that way we are getting philosophies of education of the western world from the time of Socrates to the present day. John Dewey, the great American pragmatic philosopher maintains, "If we are willing to conceive education as the process of forming fundamental dispositions, intellectual and emotional, towards nature and fellow men, philosophy may even be defined as the general theory of education' ${ }^{6}$ It means that, according to Dewey, the ultimate consideration of philosophy is the education of human being.

So, we may say that philosophy of education may be considered as the most important branch of philosophy. The areas that, among others, investigated by the philosophy of education are the purpose of education - whether the goal of education should be the act of imparting knowledge, developing intellectual independence, or instilling moral or political values; the nature of educational concepts; nature of learning of the children, nature of educational authority. This paper is an attempt to try to understand the Islamic Philosophy of Education from those perspectives.

\section{Defining Education}

First of all we may try to understand the meaning of the term 'education' by comparing what Western educational philosophy has to say and what Islam holds. According to Wikipedia, the free Encyclopedia of Education in its general sense is a form of learning in which knowledge, skills, and habits of a group of people are transferred from one generation to the next through teaching, training, research, or simply through auto didacticism. In Encyclopedia Britannica 'education' has been defined in the following way: Education can be viewed as the transmission of the values and accumulated knowledge of a society. ${ }^{7}$ In International Encyclopedia of Education it is said: Education signifies the sum total of processes by means of which a community or social group, whether small or large, transmits its acquired power and aims with a view to securing its own continuous existence and growth. ${ }^{8}$

The Islamic perspective regarding education may be found in the Holy Qur'an. The word 'education' in Arabic is 'tarbiya'. It comes from the Arabic root words raba and rabba. Raba means to increase the physical size of things. Allah says “... and (further), thou seest the earth barren and lifeless, but when We pour down rain on it, it is stirred (to life), it swells and it puts forth every kind of beautiful growth (in pairs)." (Quran 22:5). In this verse Allah used the word rabat to mean to grow and multiply. The word rabba, on the other hand, refers to humans and animals to mean to bring up or to honour the soul and raise it to greater positions. Allah says “....and say: 
"My Lord! Bestow on them (parents) Thy Mercy even as they cherished me (rabbayani) in childhood.” (Al-Qur'an 17-24). Therefore, the word tarbiya in Arabic, which is a synonym for education, means to help someone in improving gradually in attaining perfection in all the aspects of growth. In the Holy Qur'an we find the same indication.

\section{Nature of Man}

Now we may examine the nature of man, for whom the education is meant, as perceived by Islam. Human being has two aspects - body and soul. Every human being has a body, his/her physical existence, and also something that keeps him/her alive. We generally call this 'something else' as soul. Allah mentions this through different verses of Al- Qur'an. As for example, after creating the body of Adam with clay it is said "Then He fashioned him in due proportion and breathed into him something of His soul." All living organisms have soul, but of course, there is much difference between an animal soul and a human soul. We may say that human soul has two parts. One part of the soul is associated with and responsible for all the bodily desires and passions which is somewhat same as of animals but with an additional feature of developed mind. This part of soul i.e. developed mind is responsible for intellectual activities and human feelings. The other part of the human soul is unique and it has a dictating power over the activities of passions and desires of animal-like part of the human soul. We may call this part as rational part. Though the soul is to be considered as to having higher estimation than body because it contains ' $R u h$ ' from Allah, body is never to be neglected. If the soul is to work in a good way the body, in which it dwells has to be a good one. That is why Allah asks us to take good and proper diet, take medicine if needed and keep the body fit. The directions for these could be found in the
Qur'an in Sura 6 verse142, Sura 2 verse 168, Sura 5 verse 3-5, Sura 59 verse 68-69 and many others. So, we find that according to Islamic Philosophy of Education human being is a composite whole of body and soul.

In the western world Plato's philosophy of education is still esteemed. According to Plato, there are three components in the nature of a human being. These are appetite, spirit and reason. The senses and the bodily drives of human beings are referred to as appetite, human tendency towards selfassertiveness is referred to as spirit and reason is the component which is to comprehend and direct the other two components. ${ }^{10}$ In modern times, Hobbes described human beings as matter in motion, just like machines. He also described man's natural state as one where life would be "solitary, poor, nasty, brutish and short."11 John Locke also said that human minds are tabula rasa or just a blank slate at birth. After birth, according to him, data are added, and rules for processing them are formed in the mind. These are done solely by our sensory experiences. ${ }^{12}$ The $18^{\text {th }}$ century philosopher Rousseau argued that human nature was not only unfixed, but not even approximately fixed compared to what had been assumed before him. Humans are political, and rational, and have language now, but originally they had none of these things. ${ }^{13}$ Rousseau's conception of human nature influenced many philosophers like Kant, Hegel, and Marx. Most of them conceived humans having only animal-like passions.

David Hume possessed a different notion than Hobbes and Rousseau. He did not believe that all human nature are driven by variations of selfishness. He rejected what he called the "paradox of the sceptics" saying that no politician could have invented words like 'honourable' and 'shameful,' 'lovely' and 'odious,' 'noble' and 'despicable,' unless there was not some natural "original constitution of the mind." 14 So, he was of the 
opinion that there is a nobler part of the human mind which is quite higher in ability and esteem than bare animality.

So, we find that most of the idealistic philosophers of the West, especially Plato, were of the opinion that human being is a composite entity of appetite, spirit and reason. According to them, among these three components, Reason will reign. On the other hand, most of the materialists and the realists are of the opinion that humans are just a composite of matter, a bit higher than animals with the passion reigning and with no teleological factor in life.

\section{Man's mission}

Now, what is the purpose of creating such a being with bodily needs and desires like animals and also with a faculty, i.e., reason to control them, from the Islamic perspective? Is there at all a purpose or mission of human existence? Allah is all rational and all just. He has created man in the image of Himself. ${ }^{15}$ Of course, it is the rational part of the soul in which human beings resembles ${ }^{16}$ Allah. This rational part of the soul has the capacity to attain the qualities of Allah, though in a miniature scale. Allah says in the Qur'an: "So set the purpose (O Muhammad) for religion as a man by nature upright - the nature (framed) of Allah, in which He hath created Man”. ${ }^{17}$

Animals have only the bodily desires with no or very insignificant quantity of mental ability. Nor do they have the capacity to do either right or wrong. The Farishta or Angels have neither bodily desires nor reason. They are only to follow Allah's orders. Angels are programmed by Allah ${ }^{18}$ somewhat like the robots are programmed by man. So, the Angels can only do right and no wrong. Human beings are in between these two extremes. It seems that Allah wants to see whether and how much can human beings control their appetite and choose the right discarding the wrong application of reason; whether they can be the real vicegerent ${ }^{19}$ on the earth to act and rule according to Allah's Will and Purpose. Though this is a very difficult task with so much of passion, this is the mission he is sent for. The soul knew what is right when it was a part of Allah. But being a part of man it comes under the influence of forgetfulness. This forgetfulness is the cause of man's disobedience, injustice and ignorance. It is man's duty to fight against these and get the real truth with the help of reason, that is, intelligence. His intelligence may confuse him sometimes. But if he remains sincere seeker of truth and true to his real nature Allah will help him with his guidance through some or other form of insight. So, he must not be unjust to his real nature and real mission. Injustice, according to Islam, as S.N. Al-Attas puts it, "is the putting a thing in a place not its own; it is to misplace a thing; it is to misuse or to wrong; it is to exceed or fall short of the mean or limit; it is to suffer loss; it is disbelief of what is true knowing it to be true". ${ }^{20}$ So if a man acts in that way he becomes unjust to his own soul and breaks covenant with Allah.

Thus it is evident that man has a dual nature of spirit and physique. He has, like any other animals, bodily desires. He also has the capacity to know the truth through spiritual and rational faculties. He has his own self which is responsible for all of his actions. With this complex nature he is to fulfill or attain a special mission. That mission is to acquire the attributes of his creator ${ }^{21}$ as much as possible and act according to His rules i.e. to be a vicegerent of Allah on earth.

Regarding the attributes of Allah which human beings are to acquire could be found in the 99 beautiful names of Allah. These names portray the different attributes of Allah. A person may not be able to acquire all the attributes of Allah, though in a miniature form, still one should try to acquire as much as he 
can in order to become a true vicegerent of Allah. As for example, Allah is just, so human beings have to practice justice. Allah is the creator and man also should try to create something, according to his capacity. That means human beings should embody Allah's attributes and act accordingly. This, I think, is the mission of man. Another point has to be noted here. In the Holy Qur'an it is said that Allah has created life and death so that He can test who among us are good in deeds. ${ }^{22}$ The nature of these deeds is quite different than the deeds of the angels. Indications could be found from the aayat 30 of the Sura Bakara. Human beings' duty is not just to enchant Allah's praise and supremacy, like the angels do; he has duty related to worldly affairs also, both physical and mental. That is why in each namaz being sited we are asked to say, as Prophet Muhammad said to Allah during the Miraaj, 'I have come to you with my salaatoyato (prayers) and tayyebato (good deeds).

\section{Aims of Education}

On considering the above two sections i.e. the nature and the mission of man, we may say that the aim of education according to Islamic Philosophy of Education is to help or facilitate a child's learning in such a way as to acquire Allah's attributes according to one's ability (rabat) so that one can act accordingly, after being helped in developing physically (raba). Allah says "I have not created Jin and Mankind except to serve me." 23 Human being's mission is to be an effective vicegerent of Allah on earth so that he can serve Him in the best possible way. In order to achieve this mission he has to learn almost everything, because his innate skills are minimum in number. With all the endeavour the process of education from the Islamic perspective aims at producing such persons who will be able to perform their duty as vicegerent accurately.
And for this a person needs to be physically fit, mentally up right and spiritually illuminated. So the aim of education is to assist a person in achieving these abilities according to his or her disposition.

Different Western educational philosophers and philosophies have put forward a considerable amount of discussions regarding the aims of education. We may make a list of some of the aims suggested by them:

a. To conserve and perpetuate the funded capital of social experience. (primitive)

b. To create good citizens with a harmonious development of all the person's capacities. (Plato, Aristotle)

c. To make the person to be capable of salvation through a denial of material and worldly desires. (Catholicism)

d. To acquire whole of knowledge (pansophism-Bacon, Comenius)

e. To discipline the mind. (Locke)

f. To develop free spontaneous expression (Rousseau)

g. To develop child's own unique potentialities (Froeble)

h. To help in the projection of human desires (Thorndike)

i. To have more education (Dewey)

j. To practice the moral and intellectual virtues (Adler) ${ }^{24}$

If we analyze the above stated aims we shall find that each of them speak of a specific side of the human entity. Though Herbert Spencer spoke of 'complete living' as the aim of education, the specific areas he highlighted does not complete the wholeness of human life. He spoke of (i) the art of self preservation, (ii) earning a living, (iii) bearing and rearing children, (iv) social and political duties, (v) art, literature, and the like. ${ }^{25}$ He did not pay attention to the spiritual aspect of human entity. 


\section{Nature of knowledge we should strive to acquire}

So far there has been an endeavor to analyze, in brief, the nature of man and his mission. In order to develop his nature to its fullest extent and fulfill his mission the acquisition of one attribute of God is most essential and that attribute is knowledge. In Al-Qur'an and Hadith much impotence has been given on the acquisition of knowledge on the part of human beings. $^{26}$

What sort of knowledge should the human beings acquire? As their entity is a combination of two different aspects, spiritual and physical, they must acquire such knowledge which will be beneficial for both the aspects. That means they will have to acquire knowledge for the betterment of the spiritual aspect of nature as well as the physical aspect of nature. Indications as to what sort of knowledge we should sought and acquire could be found in the Qur'an and Sunnah. In this respect we may find indications from the following verse: "O Allah! Grant us in the good for world and in the good for hereafter and protect us from the punishment of the fire."27 Through this verse we can understand that we need knowledge about the world to embody the good for the world and also of the hereafter for the good of hereafter. From this verse another thing can be noticed. Here good of the world has been mentioned first and good of the hereafter in the second place. This notion could be inferred from the verse number 15 of the Sura Ahkaaf also. This verse indicates that after the age of forty we are to start thinking seriously about the spiritual development; about attaining ability or learning how to attain a good life in the here after. Before that we are to learn to be a good and successful person here, in this world.

\section{Curriculum}

On the onset subject matters of the curriculum could be divided into two broad divisions: (a) subjects that will be beneficial for the satisfaction of bodily needs, (b) subjects that will be beneficial for the fulfillment of the spiritual needs. Of course, there are some which are for both. There are a number of verses in $\mathrm{Al}$ Quran that gives the indications as to what are the most important field of investigation or study. We may highlight some of them here.

\section{a. Literacy}

Regarding the matter that literacy is the most important aspect in education, the first instance that I would like to site can be understood from an event in the life of the Prophet Muhammad (SM). At the battle of Badr in which the Prophet gained victory over his opponents, seventy people of the enemy rank were taken prisoner. These prisoners of war were literate people. In order to benefit from their education the Prophet declared that if one prisoner teaches ten Muslims how to read and write, this will serve as his ransom and he will be set free. We can freely say that this was the first formal school in the history of Islam established by the Prophet himself with all its teachers being non-Muslims. Furthermore, they were all war prisoners. So we can find and can say that the basic curriculum of the first formal school of Islam contained reading and writing that means literacy. That literacy is the first step to become educated, could be found from the fact that the first Verse that came from Allah to Prophet Muhammad is on literacy. It is: "Read; and your Lord is most bounteous, Who taught by the pen and taught men that which he new not." ${ }^{28}$ Importance of it is indicated in the following verse also: " $\mathrm{O}$ ye who believe, when you contract for a fix term, record it in writing: let a scribe write down faithfully as between you (the parties); let 
not the scribe refuse to write ...."29 Another point is evident from this verse. When both the person of the parties or any one of them is illiterate then a third person will be needed to write. In that case a breach of faithfulness may arise. So each and every person of a Muslim community should be literate. That literacy is first and foremost requirement is evident from another saying of Prophet Muhammad (Sm), "To acquire knowledge is obligatory for every Muslim”. Literacy is the first and a convenient step of acquiring knowledge.

\section{b. Language}

Human beings are not only to read and write they have to speak also. Allah maintains in the Holy Qur'an: "He has created man and taught him speech." ${ }^{30}$ Use of speech rather to be skilled in oral communication is a necessity for a person both from the perspective of worldly affair and of the spiritual that is religious affair. And it is also a well known fact that to become skilled in language one has to read a lot of literature along with practice of speaking. Practicing could be done through recitation, short speeches and debating on different topics. No doubt that these activities could be done in the best manner through a person's first language i.e. the mother tongue. We can find the indications for this in the Holy Qur'an also. Allah says, "And He never sent a messenger save with the language of his folk, that he might make (the massage) clear for them...."31 So we may say that from Islamic perspective, to learn the mother tongue or the first language properly is the first and the foremost duty of a person.

\section{c. Science}

The Holy Qur'an encourages the systematic study of the nature which is called science and use of scientific methods to satisfy our inquisitiveness which in turn will benefit the living of this world. Not only that, the scientific knowledge will help us to know and understand the Greatness of Allah also. This fact is evident from a large number of verses. As for example:

1. "Have you considered the seed you sow? (56:63)

2. "The heavens and earth were joined together, then We clove them asunder."(21:30)

3. "(Allah subjected) the sun and the moon to calculations.”(55:5)

4. "There is not an animal on the earth nor a being that flies on its wings but communities like you.”(6:95)

5. "For among rocks there are some from which rivers gush forth, others there are which when split as under send forth water....”(2:74)

6. "And verily in cattle you will find an instructive sign from what is within their bellies between excretions and blood; We produce, for your drink, milk, pure and agreeable to those who drink it."(16:66)

7. "Verily We created man from the essence of clay; then We placed him as a minute drop in a safe lodging; then we fashioned the drop into alaq (some thing that clings) then fashioned the alaq in a lump into bones; then clothed the bones with flesh and produce it as another creation.”(23:13-14)

8. "Lo! In the creation of the heavens and the earth (in) the difference of night and day are tokens (of His sovereignty) for men of understanding. Such as remember Allah, standing, sitting, and reclining, and consider the creation of the heavens and the earth, (and say): Our Lord! Thou created not this in vain.” (3:190191) 
That the use of scientific method has been encouraged could be evident if we go through the following verse carefully: "And when Abraham said (unto his Lord): My Lord! Show me how Thou givest life to the dead, He said: Dost thou not believe? Abraham said: Yea, but (I ask) in order that my heart may be at ease. (His Lord) said: Take four of the birds and cause them to incline unto thee, then place a part of them on each hill, then call them, they will come to thee in haste. And know that Allah is Mighty, Wise." ${ }^{\text {32 }}$ Through the incident of Abraham, Allah asks us not to be dogmatic all the time. We are to apply empirical and experimental methods where needed.

\section{d. History and Geography}

There are verses which indicate that we should have knowledge about the historical and the geographical perspective of the world. For example:

1. "Say travel through the earth and see how He organized the creation.”(29:20)

2. "Do they not travel through the earth so that their hearts may thus learn wisdom and their ears may learn to hear?”(22:46)

3. "Have they not traveled in the land and seen the nature of the consequence for those who were before them?’(12:109)

4. "Many were the ways that had passed away before you; travel through the earth and see what was the end of those who rejected the truth". $(4: 137)$

\section{e. Music}

Among the Muslim religious scholars there is a difference of opinion as to whether music should be cultivated or not. But the Holy Qur'an does not disapprove it. It is evident from the following verse: “And chant the Qur'an in rhythmic measure". ${ }^{33}$ We may consider another verse, "We assuredly gave Dawood grace from us. $\mathrm{O}$ ye mountains sing ye back the praises of Allah with him and ye birds (also)". ${ }^{34}$ Even Azan is being enchanted in melodious manner from the time of the Prophet Muhammad (SM.). Moreover, we find that music can bring a mood of tranquility in the atmosphere which can be beneficial for both the children and the adults. So, music can also be included in the curriculum.

\section{f. Food and Medicine}

In order to keep the body healthy we need good food and to cure it from illness we need medicine. To get these things, much knowledge is needed. Allah has given indications regarding these also in a number of verses of Al-Qur'an. As for example it is said "So eat of the lawful and good food which Allah hath provided for you, and thank the bounty of your Lord if it is Him you serve". ${ }^{35}$ In the same Sura information about medicine is there. It is said: "And thy Lord inspired the bee, saying: Choose thou habitations in the hills and in the trees and in that which they thatch; Then eat of all fruits, and follow the ways of thy Lord, made smooth (for thee). There cometh forth from their bellies a drink diverse of hues, wherein is healing for mankind. Lo! Herein is indeed a portent for people who reflect". ${ }^{36}$ There is an indication in this verse that plants are the primary source of food and medicine for human beings. So this is also an important area of knowledge in which Allah has asked us to reflect.

\section{g. Law}

As Allah orders us to look into the laws of nature which is created by Him of course; so also He orders us to look in to the 
laws of life and death, of good and evil, actions and attitudes. Human beings are to live in communities forming families through marriage. For a peaceful community living, some system governed by rules and regulations are required. We are to learn them too. Allah has put forward such rules through AlQur'an. Among them some are for better governance of day-today physical life here, some are for spiritual life for here and hereafter.

\section{h. Religious and moral education}

"He has ordained for you that religion which He recommended unto Noah, and that which We inspire in thee (Muhammad), and that which we commended unto Abraham and Moses and Jesus saying, 'Establish the religion, and be not divided therein'. .....”37 Allah ordains us to follow the religion which He has chosen for us. We must have the knowledge about the religion properly if we are to abide by His instructions. To Allah religion is a personal affair. It is indicated by the fact that personal prayer i.e. Salat or Namaz is a five-time-a-day obligatory affair while group prayers are mostly secondary in importance. So each person has to know the rituals of the personal prayers. Namaz and also Roza are obligatory from the age of 12. So before a child reaches the age of 12 he or she must be trained in the rituals of Namaz and other personal prayers. But one thing we should remember here. There is a verse in Sura Bakara: "There is no compulsion in religion". This is applicable in the case of young boys and girls also. Religion is a matter of faith and it becomes effective if there is willful acceptance. So such efforts should be taken as to make the mind of the child becomes ready to accept the faith by the time he/she reaches the age of seven. This could be done by the cultivation of the desirable qualities. And from or around this age the training for the Namaz have to be started. The readiness could be created in an affective mode through informal conversations and activities within the family. We may abide by the dictum, 'Example is better than precept'.

Religious education has another aspect. In Qur'an it is said, "And there should spring from you a group of people who invite to goodness, and enjoin right conduct and forbid indecency." ${ }^{38}$ In another verse it is said: “... when he attains full strength and reaches forty years ..... I have turned unto thee repentant and lo! I am of those who surrender”. These verses indicates that Allah wants that some of us will be there to teach others the principles of religion and these people will be those who has turned themselves towards Allah after they have attained the age of forty. So it is evident that in order to attain knowledge of Allah and His religion of that multitude so that one can present that to others, a mature brain and heart is needed. And that maturity could be attained only after the age of forty. These people will be those who will come to take up the responsibility willingly having the capacity to grasp, understand and embody the knowledge of the entity like Allah and His religion which is the matter of highest multitude.

As for the moral education, we find a lot of instructions in the Holy Qur'an. In a number of verses of Al-Qur'an Allah says not to mix up truth with falsity and never hide truth knowing full well. ${ }^{39}$ In the verses 16 to 19 of the Sura Lokman it is said that beside establishing i.e. being regular in Salat one should do and tell others to do good deeds, maintain patience in the time of difficulties, never do boasting, and should talk with a low voice. In Sura 17 Aayat 34 it is said that one should fulfill the promise. In Qur'an people are instructed not to waste and it is also said that Allah does not love those who waste. ${ }^{40}$ Allah tells us not to be greedy, ${ }^{41}$ not to be miser neither to be extravagant, ${ }^{42}$ to be grateful, ${ }^{43}$ to control anger and practice 
forgiveness, ${ }^{44}$ to be faithful regarding deposits and witnesses. ${ }^{45}$ These are only a few examples of the virtues that where mentioned in the Holy Qur'an. These are also only a few examples of places of Holy Qur'an where Allah have mentioned about the virtues that has to be embodied by the human beings. That these virtues are to be taught by the elders could be known by the incident of Prophet Lokman through the Sura Lokman.

In the western tradition in the early days the religious and moral education was folkway or customary in character. Among the ancient Greeks it was customary to draw lessons in this area from the Iliad and the Odyssey. From these Homeric poems they used to learn such virtues as piety, hospitality, courage, temperance and self-control. Their tendency was rather secular i.e. 'they looked upon life here and now as its main opportunity'. ${ }^{46}$ During the early Christian era the focus of attention was changed and the life here after became more important. As a result practice of simple living and love for the humanity was viewed as cardinal virtue of life. During the whole of the middle age and somewhat up to the modern period Christianity reined and as its cardinal virtue was asceticism, virtues concerning worldly affairs were neglected. From the eighteenth century a rise in secularist attitude towards education was again visible and secular public schools were being established. After that from the last decade of the eighteenth century 'Sunday Schools' became the main vehicle for religious and moral education. However from this sketchy exposition it could be seen that in the western world there was a swing of pendulum between religious and secular moral education. On the other hand, in Islamic Philosophy of Education we find that from the advent of Islam secular and religious moral education is residing side by side with a balancing between the two sides of the same coin.

\section{Methodology}

The methodology of assisting a person in getting education is an important area of philosophy of education. Because how and by whom our learners learn matters a lot, may that be youngsters or adults. In this respect, we may consider the verse no. 125 of the Sura Nahl: "Call to the way of your Lord with wisdom and beautiful preaching and argue with them with that which is best." This verse gives a clear indication of what could be the main points regarding the methodology according to Islamic Philosophy of education. Professor M. Ferdouse Khan says "In this verse Allah recommends a definite methodology for transmission of religious knowledge to others. In my opinion, the same methodology is applicable and effective to the transmission of any kind of knowledge, be it religious or secular." He says that this methodology has three distinct aspects or dimensions: application of wisdom, application of beautiful preaching and application of the best possible technique of debate. ${ }^{47}$

I think he has indicated the aspects very aptly. Before a person wants to help another person in getting himself educated, he himself must have wisdom. Wisdom does not come through an acquisition of knowledge, how much deep may it, on a particular area only. He must have vast practical experience on the other affairs of life and of the world also. It may vary from level to level. But whatever the level may be he must have profound knowledge on the area of teaching as well as the related fields with practical or empirical experience. He should also know the person's ability both physical and mental and his level of knowledge. These are the aspects to make a person wise and the first requisite of a person to be able to teach another person effectively. 
Secondly, he must have the ability to preach or deliver the knowledge beautifully. The aim of the acquisition of knowledge or wisdom is two fold: (a) to use the same by the person who has acquired it, (b) to transmit it to the fellow beings including the next generation. From the $67^{\text {th }}$ Aayat of $5^{\text {th }}$ Sura i.e. Sura Maidah, like others we may get the indication of this duty. From the stand point of the philosophy of education, transmission is the matter of concern. And that the transmission should be in a beautiful mode could be understood from the verse of Sura Nal cited earlier. Now what are the criteria of the 'beautiful mode'? First of all good voice quality: the voice should be soft i.e. of low pitch and it should not be harsh; it has been said in the Sura Lukman, verse 19. It should be clear and free from any kind of inertia of the tongue. ${ }^{48}$ It has to be like that so that the seeker of the knowledge can understand the speaker talking. Secondly good language: the language should be appropriate, in consideration to the target group, for the good of the educant. That the delivery of knowledge should be in the mother tongue or the first language of the target group and that is the good for them could be known from the verse 4 of Sura Ibrahim. In this verse Allah says that He has sent messengers to a nation who speak their native language so that he can make the matter clear to them, intelligible to them. So, from this verse we find a definite direction that mother tongue should be used as the medium of instruction, at least up to the stage of general level of understanding. I would suggest, being induced by the educational disciplines, it should be at least up to the level of secondary education.

Thirdly, he should have the ability to use the skill of argument or discussion. That the argument or discussion is the best way in helping a person to learn, could be known from the verses 83 of Sura Anaam and 260 of Sura Bakara. Ayaat 260 of Sura Bakara is also indicative of the fact that empirical knowledge through experiments is very much helpful for better understanding. Need of being apt in argumentation with decency could also be known from the Ayaat 46 of Sura 29.

Throughout the Holy Qur'an, in a number of places, it has been indicated that the learners, may it be children or adult, should be encouraged to develop a habit of inquisitiveness, thoughtfulness and deeper understanding. In the Aayat 50 of Sura Kaaf Allah say that, do we not look at the sky above and enquire how He has created and decorated it! In Aayat 68-71 of Sura Waqia Allah says 'Have you thought about the water you drink. .... Have you noticed the fire you light?' And in the Ayaat 99 of Sura Bani- Israil He say, 'Do not they notice that Allah who has created the sky and the world can create like them again?' Regarding the activity of deeper understanding, the following verses of Al-Qura'n, could be considered: 56:62, 2:44, and 10:6. In the verse 62 of Sura Waqia Allah asks us why do not we try to understand regarding the seeds we sow; in 44 of Bakara Allah enquire though we read Quran, do not we understand the things said in it? In 6 of Sura 10 it is said that in the change of day and night, in the things that are created in the sky and in the world there are signs for the believer who tries to understand.

So, it is quite clear that the method of teaching according to the Qur'an should be like that which will encourage and practice inquisitiveness, thoughtfulness and deeper understanding; where discussion i.e. the two-way communication will be used and where mother tongue, with good mode of speech will be the medium.

\section{Summary}

In an endeavour to explore the Islamic philosophy of education it has been said that from the Islamic perspective education is 
the means to help someone in improving gradually in attaining perfection in all the aspects of growth. Regarding the nature of man for whom the education is meant, we find that Islamic Philosophy of Education looks at human beings as a composite whole of body and soul. With this complex nature he is to fulfill or attain a special mission. That mission is to acquire the attributes of his creator as much as possible and act according to His rules i.e. to be a vicegerent of Allah on earth. On considering the nature and the mission of man, we may say that the aim of education according to Islamic Philosophy of Education is to help or facilitate a child's learning in such a way as to acquire Allah's attributes according to one's ability so that one can act accordingly, after being helped in developing physically.

As the entity of human being is a combination of two different aspects, spiritual and physical, they must acquire such knowledge which will be beneficial for both the aspects. That means they will have to acquire knowledge for the betterment of the spiritual aspect of nature, i.e. religious as well as the physical aspect of nature, i.e. secular. The curriculum has also to be arranged in that way. Along with general and primary instructions in religion, literacy in language and number, social, physical and biological sciences and other life-skills have to be included in the curriculum of the basic education. Then there will be specializations and the specialization in religious education will start from the age of forty.

Indications regarding the methodology of teaching are also there in the Holy Quran. Throughout the Holy Qur'an, in a number of places, it has been indicated that the learners, may it be children or adult should be encouraged to develop a habit of inquisitiveness, thoughtfulness and deeper understanding. Not only that, indications could also be found that teaching should be a two-way communication through discussions and question-answers. It has also been said that mother tongue is the best medium of instruction and not any other language, at least for the beginners for their better understanding, should be used.

\section{Conclusion}

In this paper an attempt has been made to understand the inner spirit of the verses of Al-Qur'an which are related to knowledge and education. In Islam, acquiring knowledge has been made compulsory for both men and women. Prophet Muhammad (SM) said, "He who goes out to look for knowledge, remains in the path of Allah until he returns". 49 Again, educated men with the ability of understanding have been asked to look at the things and events in and around him and try to understand them. And people are asked to say their prayers and do good deeds because they will be judged according to their deeds. But is it whole of it? It is true as I have said earlier that, it seems Allah wants to see whether and how much can human beings control their appetite and choose the right discarding the wrong application of reason; whether they can be the real vicegerent ${ }^{50}$ on earth to act and rule according to Allah's Will and Purpose. Does it end here! From the beginning the messengers of Allah were the perfect vicegerent of Allah; during their time and at least few generations after them there were many people who were good vicegerent. Then a time used to come when the number of good vicegerent used to come down to minimum and Allah used to send a new messenger to remind the mankind His Will and man's duty. It was quite natural because humans have a forgetful nature and they took a long time to acquire the mechanism to preserve the message of Allah perfectly and be able to multiply the same in printed form so that it can reach to the vast number of population. That was also quite natural 
because humans had to acquire that through the natural process, by and by, step by step, remaining to acquire 'hiqmat' (scientific knowledge); of course with the help Allah, not through revelation but through intelligence. After Muhammad (SM) Allah stopped giving revelations. By that time men had with them easy-to-handle paper. Then we got printing knowhow to multiply the written material with ease and now it is quite possible to let the people have the Massage of Allah on their palms. Most of the people now-a-days know what is what regarding religion and follow them earnestly. That not whole of the mankind will be good believers is known to Allah. He says, "And had your Lord willed, those on earth would have believed, all together. So, will you (o Muhammad, (SM) then compel mankind, until they become believers?"i Then why, knowing full well that situation will not be any better regarding belief or religious matters, after fifteen hundred years of Muhammad (SM), Allah is still letting the world go on!

It is said in the Qur'an, “Nay, but (man) has not done what He commanded him" ${ }^{\text {25 }}$ So, what is it that man has not done yet in spite of the command of Allah! I think man was entrusted with the task of revealing the mystery of the creation. Neither the angels nor the jinns were given that responsibility. The verses 30-33 of Sura Bakara along with the verses related to acquisition of knowledge are indicative of this fact. Through establishing salat and justice in the society we are to create a peaceful world. But that does not seems to be the ultimate end because many a time messengers of Allah and their immediate followers had created such situations. Peaceful milieu is a prerequisite of acquisition of knowledge. Sometimes Allah has destroyed the notorious nations totally and replaced them with a new nation. But now-a-days, at least for more than 2000 years He is not doing that. I think, it is because every nation, though in them some notorious people are there, has got some knowledge which is valuable in revealing the mystery of the universe. The creation of the Supreme Being is a huge and complicated thing and single human ability is just like a drop of water in the sea. Collective effort is needed for revealing the mystery. Humankind is doing that, step by step, little by little, generation after generation. That is why it is said in the Hadith, 'Wherever you find a piece if knowledge, take it, thinking it to be the lost treasure of a pious man.' 'Go even to China to seek knowledge, if the need be.' That is why that nation becomes prosperous which is a seeker of knowledge; which is creator and inventor of new things. Muslims were prosperous till they were earnest seeker of hikmat i.e. scientific knowledge along with practice of the rituals of the religion. So, I would like to conclude by saying that Islamic Philosophy of Education is such a theory, the ultimate aim of which is to produce such persons, may be small in number, who will be able to use their intellect in contributing in unveiling the mysteries of the nature. The general mass will be educated to contribute to assist them and to keep the milieu congenial.

\section{References}

1. Al Quran, 96:1-5

2. Ibid, $20: 114 ; 16: 43 ; 58: 11$

3. Qoted, Curtis, J. S., Introduction to the Philosophy of Education, London: University Tutorial Press Ltd, 1960, p. v

4. Aristotle, The Politics, 1337a \& b.

5. Russell, Bertrand. The Problems of Philosophy, New York: Henry Holt \& Co., Inc., 1912, pp. 9-10

6. Dewey, John, Democracy and Education, New York: Macmillan, 1916, p. 383

7. The New Encyclopeadia Britannica, vol, 18, 1989, p.11

8. Monroe, Paul, ed., International Encyclopedia of Education, India: Cossmo Publications, 1990 p. 398. 
9. Al Qur’an, 32:9

10. Plato, The Republic,

11. Hobbes, Thomas, Leviathan, XIII,9

12. Locke, John, An Essay Concerning Human Understanding, Kenneth P. Winkler (ed.), Indianapolis, IN: Hackett Publishing Company, 1996, pp. 33-36.

13. Rousseau, Jean-Jacques, The Social Contract, Translated by Maurice Cranston, Published by Penguin Classics, 1968, p. 136

14. Hume, David, An Enquiry into the Sources of Morals, Section 5.1

15 Al Qur'an, 38:72; 95:4

16. Ibid, $15: 29$

17. Ibid, 30:30

18. Ibid, 2:32

19. Ibid, "Your Lord said to the angels, I will create a vicegerent on earth"2:30, He it is Who made you (His) vicegerent on earth." 6:165

20. Al-Attas, S.N., "PrimaryThoughs on the Natrure of Knowledge and the Definition and Aims of Education", Aims and Objectives of Islamic Education, Holder Sloughton, Jedda, 1979, p. 27

21. Al Quran, “(We take our) colour from Allah, and who is better than Allah in colouring” 2:138

22. Ibid, $67: 1-2$

23. Ibid, $51: 56$

24. Brubacher, J.S., A History of the Problems of Education, McGraw-Hill Book Company, Inc. 1947, pp.1-22

25. Ibid, p. 16

26. Al Qur'an, "and say: My Lord! Increase me in knowledge”, 20:114

27. Ibid, 2:201

28. Ibid, 96:3-5
29. Ibid, 2:283

30. Ibid, 56:3-4

31. Ibid, $14: 4$

32. Ibid, 2:260

33. Ibid, $73: 4$

34. Ibid, 34:10

35. Ibid, 16:114

36. Ibid, 16:68-69

37. Ibid, $42: 13$

38. Ibid, 3:104

39. Ibid, 2:42

40. Ibid, 6:141

41. Ibid, $4: 32$

42. Ibid, $25: 67$

43. Ibid, 39;7

44. Ibid, 3:134

45. Ibid, 70:35

46. Brubacher, J.S., op.cit. p.322

47. Khan, Md. Ferdouse, The Quraanic Principles of Education, Islamic Foundation Bangladesh, 1988, p. 29

48. Al Qr'an, 20:27-28

49. Tirmijee

50. Al Qur'an, "Your Lord said to the angels, I will create a vicegerent on earth"2:30, He it is Who made you (His) vicegerent on earth.” 6:165

51. Ibid, 1099

52. Ibid, $80: 23$ 
